braziliensis cutaneous leishmaniasis. $\mathrm{Br} \mathrm{J}$ Dermatol 2005;153:203-5.

17 Reithinger R, Dujardin JC, Louzir H et al. Cutaneous leishmaniasis. Lancet Infect Dis 2007;7:581-96.

18 Herwaldt B. Leishmaniasis. Lancet 1999;354:1191-9.

19 Bailey MS, Green AD, Ellis CJ et al. Clinical guidelines for the management of cutaneous leishmaniasis in British military personnel. J R Army Med Corps 2005;151:73-80.

Address for correspondence: Dr EM Moore, Hospital for Tropical Diseases, University College London Hospital, Capper Street, London WC1E 6AU.

\section{The management of malaria in adults}

Karolina-Anthoula Akinosoglou, clinical research scientist; Geoffrey Pasvol, consultant in infection and tropical medicine

Department of Infection and Tropical Medicine, Imperial College London, Lister Unit, Northwick Park Hospital, Harrow

Malaria is one of the most common imported infections in travellers. ${ }^{1}$ The number of cases in travellers is trivial set against the global scale of disease, but in this age of frequent international travel it is essential that clinicians are at least aware of when to suspect, and how to diagnose malaria. Detailed specialist advice can always be sought.

\section{Epidemiology}

The five species of malaria parasites now known to affect humans differ in their geographic distribution:

- Plasmodium falciparum: most common in sub-Saharan Africa and Melanesia (Papua New Guinea and the Solomon Islands).

- P. vivax: mainly Central and South America, North Africa, the Middle East and within the Indian subcontinent.

- P. ovale: almost exclusively in West Africa.

- P. malariae: mainly in Africa.
- P. knowlesi: on the island of Borneo and other parts of South-East Asia. ${ }^{2}$

\section{Clinical features}

The clinical symptoms and signs of malaria are produced by the asexual forms in the blood which destroy red cells, localise in critical organs, obstruct the microcirculation and release 'toxins', leading to the classical malarial rigor with pronounced fever. ${ }^{3}$ The incubation period is variable, but may be as short as seven days and, exceptionally, up to 20 years. Most (>90\%) P. falciparum infections in travellers occur within six weeks after return from foreign travel. Compliance with antimalarial chemoprophylaxis cannot exclude the diagnosis.

After a prodromal period of fatigue and aching, the abrupt onset ensues of a rigor consisting of a 'cold', 'hot' and 'sweating' phase, and high temperature. In P. knowlesi infections the cycle occurs every 24 hours; in $P$. falciparum the periodicity of fever tends to be less predictable, and the fever may be continuous due to the asynchrony of parasite development. Headache, cough, myalgia (flu-like symptoms), diarrhoea and mild jaundice are non-specific symptoms of all malarias. Examination of a patient with mild malaria often

\section{Key points}

Malaria must be considered in all patients with fever or history of fever who have visited a malaria endemic country

The challenge in malaria is that of rapid diagnosis and initiation of appropriate antimalarial and supportive treatment

Physicians should be aware of the therapeutic and prognostic implications of lifethreatening falciparum versus non-falciparum malaria

Prompt recognition of the severe manifestations of malaria requires an increased level of care or referral to a specialist unit

The water-soluble artemisinin derivative, artesunate, one of the new antimalarial agents, is the current drug of choice in severe falciparum malaria rather than quinine

KEY WORDS: artesunate, malaria, quinine, severe falciparum malaria 
reveals a fever, tachycardia and little else.

\section{Severe malaria}

Definitions of the clinical manifestations of severe malaria (complications) are for the standardisation of clinical studies rather than for clinical care and must be taken in context (Table 1). ${ }^{4}$ Any degree of impairment of consciousness, prostration, jaundice, evidence of renal impairment, repeated vomiting or a parasitaemia of $2 \%$ or higher, especially in non-immune individuals and in pregnancy, should be treated parenterally. ${ }^{5}$ In our study of falciparum malaria, a parasitaemia of that level predicted a 12 -fold risk of severe disease. ${ }^{6}$ In a large study of 400 cases of severe malaria, increasing age, increased parasitaemia and decreased Glasgow Coma Score were associated with increased mortality. ${ }^{7}$

\section{Complications of severe malaria}

\section{Cerebral malaria}

The patient may pass from drowsiness to coma gradually over a few days or abruptly within 1-2 hours, often heralded by a convulsion. Most of these patients have no focal neurological signs, but occasionally they may have cranial nerve palsies, monoplegia or hemiplegia, extensor posturing, decerebrate or decorticate rigidity, dysconjugate eye movements, grinding of the teeth (bruxism) or hiccoughs. Coma may be due to direct neurological involvement, status epilepticus, severe acidosis or hypoglycaemia, each of which requires different management.

\section{Respiratory distress}

In respiratory distress there is rapid laboured breathing, sometimes abnormal in rhythm, ${ }^{8}$ resulting from an acute respiratory infection, compensation for severe metabolic acidosis, severe anaemia or pulmonary oedema. Pulmonary oedema, in turn, results from hypoalbuminaemia, iatrogenic fluid overload or direct alveolar capillary damage leading to the acute respiratory distress syndrome. Again, each of these requires different management.

\section{Table 1. Manifestations of severe falciparum malaria. ${ }^{4 *}$}

Manifestation

Cerebral malaria

Respiratory distress

Hypoglycaemia

Circulatory collapse (shock)

Bleeding

Renal involvement

and blackwater fever

Severe anaemia

Impaired consciousness of any degree, prostration (unable to sit and drink), jaundice, intractable vomiting, parasitaemia $\geqslant 2 \%$

* These definitions are used for standardisation of clinical studies and must be assessed in context. ARDS = adult respiratory distress syndrome; $B P=$ blood pressure; $D I C=$ disseminated intravascular coagulation; GCS = Glasgow Coma Scale; $\mathrm{Hb}=$ haemoglobin; $\mathrm{HCT}=$ haematocrit.

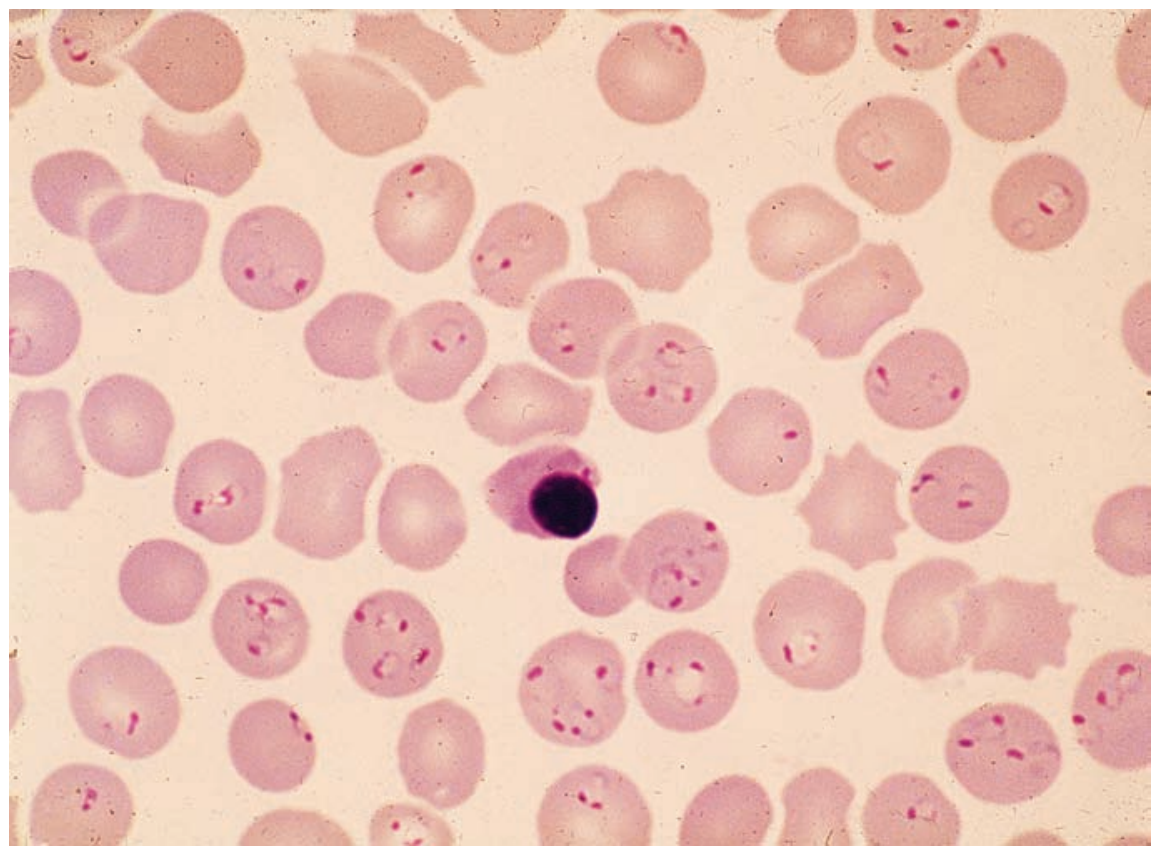

Fig 1. Blood film showing Plasmodium falciparum hyperparasitaemia.

\section{Acidosis}

Acidosis (base excess $\leqslant 12 \mathrm{mmol} / \mathrm{l}$ ), acidaemia $(\mathrm{pH}<7.3)$ or lactate above $6 \mathrm{mmol} / \mathrm{l}$ indicates a poor prognosis. It results from poor tissue perfusion, lactate generation by the parasite and anaerobic glycolysis, reduced lactate clearance by the liver, impaired renal function (acid excretion) or exogenous acids (eg salicylates).

\section{Hypoglycaemia}

Decreased conscious level may obscure the diagnosis of hypoglycaemia. Suspicion should be circumstantial, especially during quinine therapy, 
particularly if the patient is pregnant. ${ }^{9}$ The cause of hypoglycaemia is multifactorial; hyperinsulinaemia due to quinine therapy is important.

\section{Circulatory collapse (shock)}

Shock is relatively rare. The blood pressure may be at the lower end of the normal range due to vasodilatation and hypovolaemia. Hypotension is more commonly due to supervening bacterial sepsis. ${ }^{10}$

\section{Bleeding}

Despite the frequent presence of thrombocytopenia, most likely the result of diffuse sequestration of platelets, ${ }^{11}$ overt evidence of bleeding is rare in malaria. Bleeding is more likely to occur in the setting of disseminated intravascular coagulation. There is often subtle activation of the coagulation cascade in the absence of clinical bleeding. ${ }^{12}$

\section{Renal involvement and blackwater fever}

A degree of renal impairment commonly occurs in severe malaria. Acute renal failure is rare, but can occur not only during the acute parasitaemic phase but also after parasite clearance, and may be non-oliguric. Blackwater fever may be dramatic, sometimes in the setting of glucose-6-phosphate dehydrogenase (G6PD) deficiency or in a semi-immune patient given quinine, but does not invariably lead to renal impairment. ${ }^{13}$ Hyponatraemia is often self-correcting.

\section{Severe anaemia}

The anaemia of falciparum malaria is both complex and multifactorial. The fall in haemoglobin is in excess of what can be accounted for by the loss of infected red blood cells alone. Mechanisms include red cell lysis by parasites, removal of uninfected cells due to antibody sensitisation or other physicochemical changes in the spleen.

\section{Diagnosis}

Malaria must be considered in all patients with fever or a history of fever who have visited a malaria endemic country, so a travel history should be a routine part of any consultation of such patients. Malaria is a great mimic and must enter the differential diagnosis, which includes typhoid, viral illnesses such as dengue fever, influenza and hepatitis, brucellosis and respiratory, gastrointestinal and urinary tract infections.

\section{Blood films}

The definitive diagnosis of malaria is made by microscopic examination of thick and thin blood films. In falciparum malaria, mature trophozoite forms, the presence of schizonts or excessive malarial pigment present in neutrophils or macrophages might signify a worse prognosis. ${ }^{14}$
Table 2. Treatment of non-falciparum malaria.

\begin{tabular}{|c|c|c|}
\hline Drug & Dose & Comments \\
\hline $\begin{array}{l}\text { Chloroquine phosphate or } \\
\text { sulphate (each tablet } \\
\text { contains } 150 \mathrm{mg} \text { base) }\end{array}$ & $\begin{array}{l}\text { Loading dose } 600 \mathrm{mg} \text {, } \\
300 \mathrm{mg} 6 \mathrm{~h} \text { later, then } 300 \mathrm{mg} \\
\text { daily for two days (total } \\
10 \text { tablets) }\end{array}$ & $\begin{array}{l}\text { Infrequently chloroquine } \\
\text { resistance occurs requiring } \\
\text { Malarone }^{\circledast} \text {, quinine plus } \\
\text { doxycycline or Lariam }^{\circledR}\end{array}$ \\
\hline $\begin{array}{l}\text { Followed in ovale malaria } \\
\text { by primaquine }\end{array}$ & 15 mg daily for 14 days & $\begin{array}{l}\text { Not given in G6PD deficiency or } \\
45 \text { mg weekly for six weeks with } \\
\text { monitoring for haemolysis in } \\
\text { mild G6PD deficiency }\end{array}$ \\
\hline $\begin{array}{l}\text { Followed in vivax malaria by } \\
\text { increased dose of primaquine }\end{array}$ & $30 \mathrm{mg}$ daily for 14 days & Not given in pregnancy \\
\hline
\end{tabular}

G6PD = glucose-6-phosphate dehydrogenate; Lariam ${ }^{\circledast}=$ mefloquine; Malarone ${ }^{\circledast}=$ atovaquone + proguanil.
Table 3. Treatment of mild falciparum malaria.

$\begin{array}{ll}\text { Drug } & \text { Dose } \\ \text { Quinine sulphate } & 10 \mathrm{mg} \mathrm{(salt)/kg} \mathrm{(usually} \\ & 600 \mathrm{mg} \text { ) 8-hourly for 3-7 days } \\ & \text { (in practice, when parasite } \\ \text { clearance has been achieved } \\ \text { for } 24 \mathrm{~h} \text { ) }\end{array}$

Followed by:
Doxycycline

or

Clindamycin

Malarone ${ }^{\circledR}$

Riamet $^{\circledR}$

Lariam $^{\circledast}$
$200 \mathrm{mg}$ daily for seven days $450 \mathrm{mg} 3 \times$ daily orally for seven days

Four tablets daily for three days (each tablet contains atovaquone $250 \mathrm{mg}$ and proguanil $100 \mathrm{mg}$ )

If weight $>35 \mathrm{~kg}$, four tablets at $8,24,36$ and $60 \mathrm{~h}$

$750 \mathrm{mg}$ as a single dose, repeated after $6 \mathrm{~h}$

\section{Comments}

Almost all patients develop cinchonism (ringing in the ears, deafness, nausea, vomiting etc), especially if they have liver or renal impairment. Therefore reduce dose to $2 \times$ daily if parasite count falling

Not for children or in pregnancy

Can be used in pregnancy and in children at the appropriate dose

Better tolerated than quinine Main side effects are gastrointestina Some resistance reported

Relatively few side effects

Contraindicated in early pregnancy and in patients with neuropsychiatric history

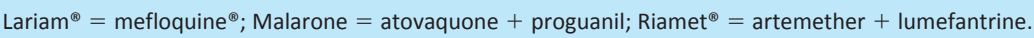




\begin{tabular}{|c|c|c|}
\hline Drug & Dose & Comments \\
\hline Artesunate & $\begin{array}{l}2.4 \mathrm{mg} / \mathrm{kg} \text { iv followed by } 2.4 \\
\mathrm{mg} / \mathrm{kg} \text { at } 12 \text { and } 24 \mathrm{~h} \text {, then } \\
2.4 \mathrm{mg} / \mathrm{kg} \text { daily as a bolus } \\
\text { until parasites cleared } \\
\text { Follow with doxycycline, } \\
\text { clindamycin, Malarone }^{\circledR} \text { or } \\
\text { Riamet }^{\circledast} \text { as for mild falciparum } \\
\text { malaria (Table } 3 \text { ) }\end{array}$ & $\begin{array}{l}\text { Can be given iv as it is water } \\
\text { soluble } \\
\text { Requires a second agent as } \\
\text { recrudescence is common }\end{array}$ \\
\hline $\begin{array}{l}\text { Quinine dihydrochloride } \\
\text { (rapid loading dose) }\end{array}$ & $\begin{array}{l}7 \mathrm{mg} \text { (salt)/kg by infusion } \\
\text { pump over } 30 \mathrm{~min} \text {, followed } \\
\text { immediately by } 10 \mathrm{mg} / \mathrm{kg} \text { over } \\
4 \mathrm{~h} \text { in } 5 \% \text { dextrose every } 8 \mathrm{~h} \\
\text { until parasitaemia is }<1 \% \text { and } \\
\text { the patient can take by mouth, } \\
\text { then quinine sulphate } 600 \mathrm{mg} \\
3 \times \text { daily until parasites have } \\
\text { cleared Follow with doxycycline, } \\
\text { clindamycin, Malarone }^{\circledast} \text { or } \\
\text { Riamet }{ }^{\circledR} \text { as for mild falciparum } \\
\text { malaria (Table } 3 \text { ) }\end{array}$ & $\begin{array}{l}\text { Can induce hypoglycaemia and } \\
\text { cardiac arrhythmias } \\
\text { Special caution should be taken } \\
\text { in the elderly and those with } \\
\text { underlying cardiovascular disease } \\
\text { Loading dose should not be given } \\
\text { to patients who have received } \\
\text { quinine, quinidine or Lariam }{ }^{\circledast} \text { in } \\
\text { the previous } 24 \mathrm{~h}\end{array}$ \\
\hline $\begin{array}{l}\text { Quinidine } \\
\text { gluconate } \\
\text { (continuous infusion) }\end{array}$ & $\begin{array}{l}10 \mathrm{mg} \text { (salt) } / \mathrm{kg} \text { (equivalent to } \\
6.25 \mathrm{mg} \text { base } / \mathrm{kg} \text { ) infused over } \\
2 \mathrm{~h} \text {, followed by continuous } \\
\text { infusion of } 0.02 \mathrm{mg} \text { (salt) } / \mathrm{kg} / \mathrm{min} \\
(0.0125 \mathrm{mg} \text { base } / \mathrm{kg} / \mathrm{min} \text { quinidine) } \\
\text { until parasites }<1 \% \text { and the patient } \\
\text { can take by mouth, then quinine } \\
\text { sulphate } 600 \mathrm{mg} 3 \times \text { daily until } \\
\text { parasites have cleared } \\
\text { Follow with doxycycline, clindamycin, } \\
\text { Malarone }{ }^{\circledR} \text { or Riamet }{ }^{\circledR} \text { as for mild } \\
\text { falciparum malaria (Table } 3 \text { ) }\end{array}$ & \\
\hline
\end{tabular}

iv $=$ intravenous; Lariam $^{\oplus}=$ mefloquine; Malarone ${ }^{\oplus}=$ atovaquone + proguanil; $^{\text {Riamet }}{ }^{\oplus}=$ artemether $+^{-}$ lumefantrine.

\section{Rapid diagnostic tests}

Based on antigen capture, rapid diagnostic tests using a monoclonal antibody to the histidine-rich protein 2 of $P$. falciparum or parasite lactate dehydrogenase of $P$. falciparum or $P$. vivax require minimal expertise but are expensive and not quantitative. $^{15}$

\section{Treatment}

The mainstay of treatment of mild malaria is the administration of specific and appropriate antimalarials. ${ }^{5}$

\section{Non-falciparum malaria}

Malaria due to $P$. vivax, $P$. ovale, $P$. malariae or $P$. knowlesi requires a stan-
Lariam $^{\circledR}$ may also be used. Quinine requires treatment to be followed up by a second agent such as doxycycline to prevent recrudescence.

Severe falciparum malaria. The management of severe falciparum malaria is a medical emergency. Patients with severe malaria should be transferred to the highest possible level of clinical care (eg a high-dependency or intensive therapy unit). Measurement of glucose, lactate and arterial blood gases should be performed in the initial assessment and blood taken for cross-matching and coagulation studies. Meticulous care must be given to fluid balance as both dehydration and overhydration can occur as a result of the disease or treatment.

Artesunate. An effective antimalarial, ideally intravenous (iv) artesunate, should be given (Table 4). Quinine is an alternative. Artesunate has distinct advantages over quinine in its effectiveness and toxicity profile. In large randomised trials, artesunate gave 35\% reduction in mortality in Asian adults and children ${ }^{17}$ and $23 \%$ reduction in African children. ${ }^{18}$ Artesunate is not yet produced to good manufacturing practice, and hence does not have a product licence in Europe or Food and Drug Administration approval in the USA.

Artesunate can be used on a named patient basis, where available, in the UK and via an investigational-new-drug application from the Centers for Disease Control and Prevention in the USA. ${ }^{19}$

\section{Blood and exchange transfusion}

Blood transfusion may be of benefit in patients with respiratory distress and metabolic acidosis. In units with appropriate facilities, complicated hyperparasitaemia may be treated with exchange transfusion. ${ }^{20}$ The use of the latter is controversial, but should be considered for all patients in whom the parasitaemia exceeds an arbitrary $30 \%$. It is also indicated in those in whom parasitaemia is lower but who have manifestations of severe complicated malaria, patients who 
have underlying medical conditions, are elderly or pregnant. ${ }^{21}$

\section{Supportive management}

Adequate fluid replacement, but avoiding fluid overload, is essential. Elective ventilation needs to be considered, especially if there is severe acidosis, evidence of raised intracranial pressure or respiratory failure of any cause. Dialysis or haemofiltration may be required. Bacterial superinfection is common in malaria and must be suspected and empirically treated with broad-spectrum antibiotics such as a third-generation cephalosporin.

\section{Conclusions}

Malaria must enter the differential diagnosis of any febrile patient who has travelled to an endemic area. In falciparum malaria, it is important to make the diagnosis promptly if the severe manifestations are to be avoided. The use of the artemisinin derivatives, most notably iv artesunate, has the potential to dramatically reduce the mortality of severe and life-threatening falciparum malaria.

\section{References}

1 Smith AD, Bradley DJ, Smith V et al. Imported malaria and high risk groups: observational study using UK surveillance data 1987-2006. BMJ 2008;337:a120.

2 Cox-Singh J, Davis TM, Lee KS et al. Plasmodium knowlesi malaria in humans is widely distributed and potentially life threatening. Clin Infect Dis 2008;46: 165-71.

3 Pasvol G. Cell-cell interaction in the pathogenesis of severe falciparum malaria. Clin Med 2001;1:495-500.

4 Severe falciparum malaria. World Health Organization Communicable Diseases Cluster. Trans R Soc Trop Med Hyg 2000;94(Suppl 1):S1-90.

5 Lalloo DG, Shingadia D, Pasvol G et al. UK malaria treatment guidelines. J Infect 2007;54:111-21.

6 Phillips A, Bassett P, Zeki S, Newman S, Pasvol G. Risk factors for severe disease in adults with falciparum malaria. Clin Infect Dis 2009;48:871-8.

7 Bruneel F, Tubach F, Corne P et al. Severe imported falciparum malaria: a cohort study in 400 critically ill adults. PLoS One 2010;5:e13236.

8 Marsh K, Forster D, Waruiru C et al. Indicators of life-threatening malaria in African children. $N$ Engl J Med 1995;332:1399-404.

9 White NJ, Warrell DA, Chanthavanich P et al. Severe hypoglycemia and hyperinsulinemia in falciparum malaria. $N$ Engl J Med 1983;309:61-6.

10 Berkley J, Mwarumba S, Bramham K, Lowe B, Marsh K. Bacteraemia complicating severe malaria in children. Trans $R$ Soc Trop Med Hyg 1999;93:283-6.

11 Karanikas G, Zedwitz-Liebenstein K, Eidherr $\mathrm{H}$ et al. Platelet kinetics and scintigraphic imaging in thrombocytopenic malaria patients. Thromb Haemost 2004;91:553-7.

12 Clemens R, Pramoolsinsap C, Lorenz R et al. Activation of the coagulation cascade in severe falciparum malaria through the intrinsic pathway. Br J Haematol 1994;87:100-5.

13 Tran TH, Day NP, Ly VC et al. Blackwater fever in southern Vietnam: a prospective descriptive study of 50 cases. Clin Infect Dis 1996;23:1274-81.
14 Kremsner PG, Valim C, Missinou MA, et al. Prognostic value of circulating pigmented cells in African children with malaria. $J$ Infect Dis 2009;199:142-50.

15 Murray CK, Gasser RA Jr, Magill AJ, Miller RS. Update on rapid diagnostic testing for malaria. Clin Microbiol Rev 2008;21:97-110.

16 Griffith KS, Lewis LS, Mali S, Parise ME. Treatment of malaria in the United States: a systematic review. JAMA 2007;297:2264-77.

17 Dondorp A, Nosten F, Stepniewska K, Day N, White N; South East Asian Quinine Artesunate Malaria Trial (SEAQUAMAT) group. Artesunate versus quinine for treatment of severe falciparum malaria: a randomised trial. Lancet 2005;366:717-25.

18 Dondorp AM, Fanello CI, Hendriksen IC et al; AQUAMAT group. Artesunate versus quinine in the treatment of severe falciparum malaria in African children (AQUAMAT): an open-label, randomised trial. Lancet 2010;376:1647-57.

19 Rosenthal PJ. Artesunate for the treatment of severe falciparum malaria. $N$ Engl J Med 2008;358:1829-36.

20 Riddle MS, Jackson JL, Sanders JW, Blazes DL. Exchange transfusion as an adjunct therapy in severe Plasmodium falciparum malaria: a meta-analysis. Clin Infect Dis 2002;34:1192-8.

21 Wilkinson RJ, Brown JL, Pasvol G, Chiodini PL, Davidson RN. Severe falciparum malaria: predicting the effect of exchange transfusion. QJM 1994;87: 553-7.

Address for correspondence: Professor G Pasvol, Department of Infection and Tropical Medicine, Imperial College London, Lister Unit, Northwick Park Hospital, Harrow, Middlesex HA1 3 UJ. Email: g.pasvol@imperial.ac.uk 